\title{
NAMPT Gene
}

National Cancer Institute

\section{Source}

National Cancer Institute. NAMPT Gene. NCI Thesaurus. Code C24661.

This gene plays a role in the regulation of B-cell colony formation. 